\title{
SEJARAH DAN EKSISTENSI LDII DI KELURAHAN MENDAHARA ILIR KECAMATAN MENDAHARA KABUPATEN TANJUNG JABUNG TIMUR
}

\author{
Nur Azizah ${ }^{1}$, Samsul Huda $^{2}$, Mina Zahara ${ }^{3}$ \\ ${ }^{1,2,3}$ UIN Sulthan Thaha Saifuddin Jambi \\ minazahara19@uinjambi.ac.id
}

\begin{abstract}
Abstrak
Lembaga Dakwah Islam Indonesia (LDII) merupakan salah satu organisasi sosial masyarakat yang menjelma menjadi salah satu ormas Islam yang ternyata sulit diterima apalagi mendapat respon positif di masyarakat, bahkan kadang muncul pula labeling sesat oleh beberapa pihak. Hakikat ajaran dan pemikiran yang dikembangkan para pengikut ormas ini banyak dipertanyakan oleh berbagai pihak, karena mereka masih bersikap selektif terhadap orang baru dan tidak mau terbuka terhadap pihak terkait. Pengakuan mereka bahwa mereka sudah lepas dari ajaran Darul Hadits yang difatwakan sesat oleh MUI tidak mudah untuk mendapat respon positif. Sementara kenyataan di lapangan warga yang termasuk pengikut LDII menampakkan keselarasan dengan umat Islam dari kelompok lain hanya dalam hal yang bersifat sosiologis semata, bukan dalam ideologi dan pemikiran. LDII telah mengalami pasang surut sejak awal keberadaannya di Mendahara Ilir, meski sempat ditolok oleh masyarakat, namun LDII tetap eksis berkembang hingga sekarang di Mendahara Ilir, Kecamatan Mendahara Kabupataen Tanjung Jabung Timur.
\end{abstract}

Kata Kunci: Organisasi Keagamaan, LDII, Mendahara Ilir

\section{PENDAHULUAN}

Organisasi keagamaan mempunyai peranan penting dalam kehidupan manusia. Salah satunya organisasi keagamaan yang ada di Indonesia ialah LDII, Lembaga Dakwah Islam Indonesia (selanjutnya disebut LDII) merupakan sebuah organisasi kemasyarakatan yang berkembangan pesat saat ini. LDII adalah organisasi yang banyak mempunyai banyak kegiatan diantaranya membangun masjid, pondok-pondok pesantren mengadakan grup-grup pengajian, penataan kader-kader serta aktif terjun ke bidang pendidikan dan berbagai kegiatan sosial. LDII di dirikan pada tahun 1951 oleh H. Nur Hasan Ubaidillah. (Ottoman, 2014:19). Jauh sebelum nama LDII terkenal, di kenal nama-nama seperti: Darul Hadits, Islam Jama'ah, Jajasan Pendidikan Islam Djama'ah (JPID), Gugus Depan 
Pramuka Khusus Islam, LEMKARI dan YAKARI (di Jawa Tengah) lalu LDII untuk seluruh Indonesia. (Ottoman, 2014:20)

Lembaga Dakwah Islam Indonesia memiliki misi untuk berdakwah kepada masyarakat luas dimana dakwah mereka ditujukan untuk mengembalikan ajaran Islam yang menurut mereka sudah bercampur baur dengan kebudayaan nenek moyang, mereka menjadikan dasar Al-Qur'an dan hadits sebagai pedoman dari dakwah mereka sehingga tidak jarang banyak masyarakat yang beranggapan organisasi ini kaku dan tidak menerima landasan hukum selain al-Qur'an dan Hadits. (Baso`, Ketua LDII Mendahara, Wawancara). Keberadaan LDII disinyalir mempunyai akar kesejarahan dengan Darul Hadits/ Islam Jama'ah yang di dirikan oleh H. Nurhasana al-Ubaidah Lubis pada tahun 1951. Setelah aliran ini dilarang pada tahun 1971, kemudian berganti nama dengan Lembaga Karyawan Islam (LEMKARI) pada tahun 1972, selanjutnya LEMKARI 1972 tersebut di ganti nama lagi dengan Lembaga Karyawan Dakwah Islam pada tahun 1981. Kemudian berganti nama lagi dengan Lembaga Dakwah Islam Indonesia (LDII) pada tahun 1990 sampai sekarang. (Ottoman, 2014:18)

Organisasi LDII ini sempat mendapat keritikan hangat oleh masyarakat maupun pemerintah sewaktu bernama Lemkari. Tidak dipungkiri bahwa beberapa kali organisasi ini dapat serangan dari Lembaga Keagamaan lain karena keberadannya yang tidak bisa lepas dari Islam Jama'ah / Darul Hadits. Eksistensi pengikut LDII inipun mendapat perlakuan yang tidak menyenangkan diberbagai daerah. Meskipun demikian, LDII tetap berdiri sampai saat ini, bahkan sangat kokoh dan solid di tengah banyaknya paham keagamaan. LDII semakin berani dalam menyebar cabang-cabang gerakannya di berbagai daerah. (Hidayat, 2008:28). Namun ketika LDII masuk ke Mendahara Ilir pada 1 juli 1972 masyarakat menolak, karena ajarannya keagamaan LDII berbeda dengan pengamalan agama masyarakat sekitar. LDII masuk ke Mendahara dan memisahkan diri dari masyarakat dan mereka membentuk kelompok mereka sendiri. Hal ini terjadi karena antara keduanya memiliki pemahaman dan pemikiran keagamaan yang berbeda. Walaupun demikian, sejak tahun 2007 intraksi dan hubungan antara keduanya dapat berjalan dengan harmonis saling 
menghormati dan menghargai perbedaan, meski ditolak LDII masih tetap bertahan.

Berdasarkan informasi yang didapat penulis saat melakukan penelitian awal pada tahun 1975 jumlah anggotanya 30 orang dari jumlah keanggotaan LDII sekarang, dimana jumlah anggota LDII sekarang 200 orang. Dari sini lah mengapa organisasi LDII masih tetap eksis dan bertahan sampai sekarang dan dapat merubah cara beragama dan cara hidup masyarakat. (Baso`, Ketua LDII Mendahara, Wawancara) maka dari itu, dikarnakan mendapatkan penolakan dan masih berkembang dan organisasi ini dapat mengubah cara hidup masyarakat, penulis merasa tertarik untuk membahas mengenai Sejarah dan Eksistensi LDII di Kelurahan Mendahara Ilir, Kecamatan Mendahara, Kabupaten Tanjung Jabung Timur.

\section{KERANGKA TEORI TEORI DIFUSI}

Menurut teori ini kebudayaan manusia itu pangkalnya satu, dan di satu tempat yang tertentu, yaitu pada waktu mahluk manusia baru saja muncul di dunia ini. Kemudian kebudayaan induk itu berkembang, menyebar, dan pecah ke dalam banyak kebudayaan baru, karena pengaruh keadaan lingkungan dan waktu. Dalam proses memecah itu bangsa-bangsa pemangku kebudayaan-kebudayaan baru tadi tidak tetap tinggal terpisah. Sepanjang masa dimuka bumi ini senantiasa terjadi gerak perpindahan bangsa-bangsa yang saling berhubungan serta saling mempengaruhi. (Koentjaraningrat, 1982:111) Jadi organisasi LDII disinyalir akar kesejarahan dengan Darul Hadits/ islam jamak yang di dirikan H. Nurhasan alUbaidah Lubis pada tahun 1951. Madigol pernah bersekolah di SR (sekolah rakyat), setelah itu dia belajar dengan kyai al- Ubaidah dari Batu Ampar kegiatannya mengaji dan melakukan wirid di sebuah kuburan keramat, nama gurunya itulah kemudian dipakai dibelakang namanya.

Pada tahun 1972 ia berangkat haji, dan sepulang dari itu namanya menjadi H. Nurhasan al- Ubaidah adapun lubis itu adalah panggilan pada muridnya, singkatan dari "luar biasa". Untuk menyatakan kedudukannya, maka di depan 
namanya ditambah kata Imam dan di belakangnya di tambah nama Amir. Pada tahun 1933 dan pendapat lain1937/1983 ia berangkat lagi ke Mekkah, menurut pendapat pertama ia belajar Hadits Bukhori-Muslim kepada Syeh Abu Umar Hamdani dari Marokko. Ia juga belajar di Madrasah Darul Hadits yang tidak jauh dari masjidil haram. Nama darul hadits ini yang kemudian di pakai untuk nama pesantrennya kelak. Menurut pendapat ini, berdasarkan cerita $\mathrm{H}$. Khoiri yang bermukim di sana, bahwa Nurhasan tidak jelas kerjanya. Hanya karena sering muncul di Masjidil Haram, akhirnya ia diizinkan tinggal di asrama yang dipimpin oleh H. Khoiri. Menurutnya juga, kemungkina besar Nurhasan masuk pondok perdukunan yang saat itu masih cukup banyak di Saudi Arabiyah. Di kuatkan lagi dengan konfirmasi Khozin ke Mekkah, maka datanglah berita dari Syekh Muhammad Abdul Hadi, Direktur Madrasah Darul Hadits di Mekkah dan Syekh Abdullah bin Muhammad bin Humaid, Direktur Umum Inspeksi Agama di Masjidil Haram bahwa tidak benar ada orang yang bernama Nurhasan Al-Ubaidah yang belajar di sana antara tahun 1929-1941. Madrasah itu sendiri baru didirikan pada tahun 1956. Apabila diperhatikan, pendapat kedua ini lebih identuk dengan Nurhasan, bila dirunut kepada latar belakang kesenangannya pada masalahmasalah bid'ah dan perdukunan. Apalagi dengan adanya informasi langsung dari Mekkah bahwa Madrasah Darul Hadits baru berdiri pada tahun 1956, itu artinya beberapa tahun setelah Nurhasan meninggalkan Mekkah, tepatnya pada tahun 1941. Sepulang dari Mekkah ia membuka pengajian di kediri. Pondok yang ia asuh pada mulanya biasa-biasa saja, baru pada tahun 1951 diproklamasikan dengan nama Darul Hadits. Dari pondok inilah H. Nurhasan memulai penyebaran dakwahnya. (Ottoman, 2014:20). Berdasarkan teori ini dapat dijelaskan bahwa Lembaga Dakwah Islam Indonesia dapat merubah cara atau pola hidup masyarakat dengan adanya organisasi ini.

\section{EKSISTENSI}

Eksistensialisme berasal dari kata eksistensi, eksistensi berasal dari bahasa inggris yaitu excitence, dari bahasa latin existere yang berarti muncul, ada, timbul, memilih keberadaan aktual. Eksitensi dalam kamus besar indonesia adalah 
keberadaan, adanya, keadaanya, kehidupan. Menurut ilmiah eksistensi adalah keberadaan wujud yang nampak adanya suatu yang membedakan antara sutu benda dengan benda yang lain. (Maendra, 2017:151)

Dalam penelitian ini yang di maksud dengan eksistensi adalah keberadaan LDII di Kelurahan Mendahara Ilir Kecamatan Mendahara Kabupaten Tanjung Jabung Timur. Guna untuk mengetahui keberadaan LDII serta mengetahui ajaran yang di lakukan LDII.

\section{LEMBAGA DAKWAH ISLAM INDONESIA (LDII)}

Sejarah Indonesia sebelum masa prakemerdekaan sampai kemerdekaan banyak agama dalam masyarakat ialah MUI, Muhammadiyah, dan NU salah satunya ialah LDII. LDII di sinyalir mempunyai akar kesejarahan dengan Darul Hadits/ Islam Jama'ah yang di dirikan oleh H. Nurhasan al-Ubaidah lubis pada tahun 1951. Jauh sebelum nama LDII terkenal, dikenal dengan nama seperti: Darul Hadits, Islam Jama'ah, Jajasan Pendidikan Islam Djama'ah (JPID), Gugus Depan Pramuka Khusus Islam, LEMKARI dan YAKARI (di Jawa Tengah) lalu LDII untuk seluruh Indonesia. Setelah aliran ini di larang pada tahun 1971, kemudian berganti menjadi LEMKARI pada tahun 1972, selanjutnya tahun 1981 menjadi Lembaga Karyawan Dakwah Islam kemudian berganti nama lagi dengan Lembaga Dakwah Islam Indonesia (LDII) tahun 1990 sampai sekarang.(Ottoman, 2014:18-20)

Lembaga Dakwah Islam Indonesia memiliki misi untuk berdakwah kepada masyarakat luas dimana dakwah mereka ditujukan untuk mengembalikan ajaran Islam yang menurut mereka sudah bercampur baur dengan kebudayaan nenek moyang, mereka menjadikan dasar Al-Qur'an dan hadits sebagai pedoman dari dakwah mereka sehingga tidak jarang banyak masyarakat yang beranggapan organisasi ini kaku dan tidak menerima landasan hukum selain al-Qur'an dan Hadits.(Baso`, Ketua LDII mendahara, Wawancara)

Perkembangan LDII sekarang, dapat di lihat dari beberapa periode pertama sekitar tahun 1940-an, ini adalah masa awal H. Nurhasan (Maligol) menyampaikan ilmu Mangul-Musnad-Musttashi yaitu al-qur'an dan Hadits. Periode kedua tahun 1951, adalah masa membangun asrama pengajian Darul 
Hadits berikut pesantren-pesantren di Jombang dan Kediri. Periode ketiga tahun 1960, adalah masa periode bai'at kepada Madigol. Yaitu ketika ratusan Jama'ah pengajian Asrama Mangul Qur'an dan Hadits di Desa Gading. (Ottoman, 2014:18-20) Selanjutnya periode keempat, penyebaran doktrin bai'at dan mengajak anggota sebanyak-banyaknya, setelah masa bai'at sang Madigol atau masa LEMKARI sampai dengan saat LEMKARI dibekukan di seluruh Jawa Timur atas desakan keras Majelis Ulama Indonesia (MUI). Periode kelima, masa LEMKARI berganti nama tahun 1990/1991 menjadi LDII hingga sekarang. Masa ini disebut masa kemenangan, sebab LDII berhasil go-internasional.

Keberadaan LDII sangat berkembangan luas sampai sekarang dan mulai menyebar ke Jambi. Jambi termasuk salah satu miniaturnya Indonesia, karena pada saat itu hampir seluruh suku yang ada di indonesia terdapat di Kota Jambi. Pada dasarnya, belum ada data yang dapat di jadikan acuan untuk mengetahui secara pasti kapan LDII berdiri di Kota Jambi. Namun, dari beberapa sumber yang layak mengatakan bahwa lembaga ini telah ada sejak akhir tahun 70-an atau awal tahun 80-an. Dalam kiprahnya di tengah masyarakat, LDII Kota Jambi memiliki tempat tersendiri yang terpisah dari masyarakat lingkungan sekitar. Berdasarkan pada pengamatan awal dilokasi dimana LDII berada dalam menjalankan aktivitas sosial keagamaan, jama'ah LDII terkesan tertutup bagi umat Islam Sekitarnya.(Sya`roni, 96)

Menurut K. H. Zainuddin M.Z bahwa LDII adalah aliran yang pernah dilarang oleh pemerintah, tetapi karna berjanji akan berbenah diri, maka kehadiran dan gedungnya di Kota Kediri diresmikan Menteri Dalam Negeri Rudini saat itu. LDII adalah wajah baru dari Darul Hadits, Islam Jama'ah, atau LEMKARI yang keberadannya perlu di kaji masyarakat dan pemerintah.

Sementara itu, Lembaga Pengkajian dan Penelitian Islam (LPPI) berpendapat bahwa "LDII adalah penjelmaan atau wajah baru dari paham agama yang berakar kesejarahan dari Darul-Hadits, Islam Jama'ah yang secara resmi telah dilarang oleh Pemerintah RI berdasarkan Surat Ketetapan dari Jaksa Agung tahun 1971: dan LDII adalah nama baru dari LEMKARI pada tahun 1981”. 
Memperhatikan Undang-undang Nomor 8 Tahun 1985 tentang Organisasi Kemasyarakatan, Peraturan Pemerintah Nomor 18 Tahun 1986, Peraturan Mentri dalam Negeri Nomor, 33 tahun 2012 dan surat dari Ketua Lembaga Dakwah Islam Indonesia (LDII) Nomor SUM-07/E.5/XI/2014, tanggal 04 November 2014 perihal permohonan izin terdaftar, setelah diadakan penelitian dokumen/berkas dan penelitian lapangan, dengan ini Badan Kesatuan Bangsa, Politik dan Perlindungan Masyarakat.

Dapat menerima Pernyataan Klarifikasi tingkat Nasional dan Dewan Pimpinan LDII Pusat, yang menyatakan bahwa:

a) LDII telah mengganut pradigma baru

b) LDII bukan penerus Islam Jama'ah/ Darul Hadits ataupun mengajarkan ajaran Islam Jama'ah.

c) LDII tidak menggunakan atau menganut sistem ke-amiran.

d) LDII tidak menggagap orang Islam diluar kelompok orang kafir atau najis.

e) LDII bersedia bersama dengan ormas-ormas Islam lainnya, mengikuti landasan berfikir keagamaan sebagaimana yang di tetapkan MUI.

1. Mengharuskan agara Klarifikasi dilakukan juga oleh pengurus LDII tingkat provinsi Kabupaten/ Kota. Sebagaimana yang dilakukan Dewan Pimpinan Pusat LDII ke Pada MUI Pusat.

2. Menyarankan agar Dewan Pimpinan Pusat sesegera mungkin melakukan Munas/Rakernas dan membuat keputusan mengenai hal tersebut sehingga terjadi persamaan persepsi dimana klarifikasi LDII sampai pada tingkat yang terbawah.

Data ini di ambil dari SK MUI Pusat tentang keberadaan organisasi Lembaga Dakwah Islam Indonesia (LDII).

\section{METODE PENELITIAN}

Dalam penelitian ini peneliti menggunakan penelitian yang berbentuk Deskriptif Kualitatif (Penelitian Lapangan/ Field Research). Penelitian Deskriptif ini bermaksud mendeskripsikan atau menggambarkan sejumlah variabel yang berkenaan dengan masalah dan unit yang diteliti. Dalam penelitian ini penulis 
telah mendeskripsikan bagaimana sejarah LDII, eksistensi serta perkembangannya di Kelurahan Mendahara. Metode penelitian penelitian yang digunakan adalah metode sejarah sebagaimana yang dikemukakan Gilbert J. Bahwa metode penelitian sejarah adalah secara efektif, menilainya secara kritis, dan mengajukan sintesis dari hasil yang dicapai dalam bentuk tertulis. Senada dengan pengertian ini Louis Gottschalk menjelaskan metode sejarah sebagai proses menguji dan menganalisis kesaksian sejarah guna menemukan data yang otentik dan dapat di percaya, serta usaha sintesis atas data semacam itu menjadi kisah sejarah yang dapat di percaya. (Abdurrahman, 2011:103). Berdasarkan pengertian diatas, para ahli ilmu sejarah sepakat untuk menetapkan empat kegiatan pokok di dalam cara meneliti sejarah. Istilah-istilah yang digunakan bagi empat langkah itu yaitu : heuristik, kritik atau verifikasi, interpretasi, dan historiografi.

\section{TEMUAN DAN PEMBAHASAN}

\section{SEJARAH BERDIRINYA LDII DI MENDAHARA ILIR}

Organisasi Lembaga Dakwah Islam Indonesia atau disingkat LDII sebagai kelanjutan organisasi sosial Kemasyarakatan Lembaga Karyawan Dakwah Islam Indonesia yang didirikan pada tanggal 1 Juli 1972 di Surabaya, Jawa Timur. (ADART LDII Pasal 1) Lembaga Dakwah Islam Indonesia merupakan wahana bagi pendidikan dakwah keagamaan dan lembaga pendidikan kemasyarakatan dalam arti luas dan terpadu, bersifat independen, mandiri, terbuka, moderat, majemuk, dan setara (egaliter), guna mewujudkan kebahagiaan hidup berdasarkan keselarasan, keserasian, serta keseimbangan dunia dan akhirat. Lembaga Dakwah Islam Indonesia bertugas melaksanakan dakwah Islam dengan berpedoman pada kitab suci Al-Qur'an dan Hadits dengan segenap aspek pengamalan dan penghayatan beragama sehingga dapat memberikan hikmah dan dorongan untuk mewujudkan tujuan Organisasi.

Lembaga Dakwah Islam Indonesia (LDII) pertama kali berdiri pada tanggal 01 Juni 1972 di Kelurahan Mendahara Ilir Kecamatan Mendahara Kabupaten Tanjung Jabung Timur, yang membawa LDII ke Mendahara ialah H. Mursidin. Dari keterangan Bapak Jumadi H. Mursidin adalah seorang yang kaya 
dan mempunyai banyak tanah, H. Mursidin ini menawarkan kepada kedua orang tua dari bapak Jumadi ini untuk masuk organisasi LDII dengan memberikan sebagian tanah oleh orang tua bapak Jumadi. Tetapi, mereka menolak hal tersebut. (Jumadi, Anggota LDII Mendahara, Wawancara) Sehingga anggota pada tahun itu hanya sedikit dan tidak sebanyak sekarang.

"Menurut bapak Baso Palettei degaga makkundrai majilbab seliwena LDII. Nampi makkundrai maka dari itulah napidangi Islam Jamak. Karna pakainnya tatutu' dan Islam Jamak itu artinya perkumpulan”. (Baso', Ketua LDII Mendahara, Wawancara)

Artinya:

"Menurut bapak Baso Palettei, tidak ada perempuan yang memaki jilbab selain LDII. Baru sekarang lah orang tau bahwa perempuan harus memakai jilbab, maka dari itulah di sebut islam jamak. Karna pakainnya tertutup dan islam jamak artinya perkumpulan".

Menurut Ibu Susi anggota LDII sekaligus anak dari Bapak Baso' Palettei cuman bedanya LDII dengan orang biase kalau LDII tu sudah tau paham aurat itu tidak boleh nampak dan sehelai rambut pun tidak boleh nampak, orang-orang LDII itu walaupun keluar rumah harus pakai jilbab. Dan yang bukan muhrim juga tidak boleh bersentuhan laki-laki dan perempuan itu bedanya dengan yang lain, kan organisasi itu banyak organisasi itu ada 73 golongan salah satunya organisasi LDII. Cuman bedanya kami ini sudah paham bahwa laki-laki dan perempuan tidak boleh bersentuhan, dan aurat itu benar-benar dijaga, tidak boleh terlihat yang bukan muhrim itu bedanya,pengajian tertib, pengajian Qur'an Hadits, sholat tertib lima waktu itu bedada.Hanya saja cara pangdang atau keyakinan yang mereka jalankan berbeda Islam Jamak mengkaji Al-Qur'an dan Hadits, karna bagi mereka jika kita hanya pintar mengaji tetapi tidak tau artinya itu menurut mereka percuma karna setiap bacaan mengadung arti atau makna yang berbeda pula. (Susi, Anggota LDII Mendahara, Wawancara)

Adapun nama-nama pengurus LDII (Lembaga Dakwah Islam Indonesia) yaitu:

\section{a. Mursidin}



b. H. Dawik
c. H. Renreng
d. H. Padang
e. Basok palette

Setelah membentuk organisasi ini terjadi permasalahan atau konflik antar masyarakat dengan anggota LDII, Masyarakat ingin membubarkan mereka karena di anggap agama baru oleh masyarakat dan tidak sesuai dengan ajaran mereka, sedangkan LDII hanya menganut ajaran Qur-an dan Hadits sebagai pedoman mereka.

Berdasarkan observasi penulis selama melakukan penelitian dilapangan, seperti keberadannya di Kaelurahan Mendahara Ilir, berjalan baik dan tidak mengganggu masyarakat sekitar maupun sosial ekonomi masyarakat sekitar. Bahkan ia selalu merespon apapun program baik dari pemerintah setempat maupun lingkungan setempat. Mereka selalu ikut apapun itu seperti gotong royong, kegiatan sosial agama, serta mau ikut hajatan atau pengajian dirumah orang yang meninggal apabila di undang karena mereka mempunyai rasa kebersamaan yang tinggi. Hal ini sama apa yang di katakan kelompok LDII dalam wawancara kepada penulis.

"Baik, Interaksi sosial kelompok kami dengan masyarakat setempat ini berjalan dengan baik dan kami selalu merespon apapun program dari pemerintah setempat atau lingkungan setempat, seperti kegiatan gotong royong kami selalu ikut, Kegiatan tebar qurban setiap Raya Idul Adha kami selalu membagikan daging kurban kepada masyarakat sekitar bagi yang sedang terkena musibah. Dan banyak juga hal yang lain dek. Seperti acara kegiatan sosial keagamaan, di acara tauziahan kami undang untuk bergabung, kami pun selalu ikut”. (Baso`, Ketua LDII Mendahara, Wawancara)

Hal serupa juga sama dengan yang dikatakan Ketua LDII dalam wawancara kepada penulis.

" Bahkan Kelompok die ini merupakan organisasi sosial masyarakat yang selalu aktip dalam kebersamaan dan kesatuan dalam sosialisasi masyarakat 
maupun agama. Interasinnya, dengan masyarakat sekitar berjalan baik dan selalu merespon apapun program baik dari pemerintah setempat maupun lingkungan setempat. Mereka selalu ikut apapun itu karena mereka mempunyai rasa kebersamaan yang tinggi. Seperti gotong royong, kegiatan sosial agama ia bergabung dengan masyarakat sekitar hari besar nabi, Arisan ibu-ibu kelompok mereka ini bergabung dengan ibu-ibu masyarakat sekitar, hajatan atau yasinan orang meninggal masyarakat sekitar kelompok mereka mau bergabung kalau mereka di undang." (Baso`, Ketua LDII Mendahara, Wawancara)

Dari hasil wawancara ini penulis dapat menyimpulkan, bahwa kelompok mereka warga LDII dengan masyarakat sekitar berjalan dengan baik intraksi sosial masyarakatnya, ekonomi maupun sosial agamannya.

Kelompok mereka ini selain interaksi sosialnya dengan masyarakat sekitar mereka juga mempunyai rasa kebersamaan dan kebersatuan antar sesama Organisasi yang ada di Kelurahan Mendahara Ilir. Mereka juga memiliki hubungan yang baik dalam menjalankan kegiatannya sesama organisai baik itu NU maupun Muhammadiyah serta yang lainnya juga. Hal ini di katakan oleh Bapak Baso’ dalam wawancaranya kepada penulis.

"Organisasi kami ini bukan sekedar mempunyai hubungan yang baik dengan masyarakat sekitar, tapi juga sesama organisasi yang ada di jambi baik dalam kegiatan Islam maupun dalam acara keagamaan seperti melakukan rapat atau untuk menetakan AD-ART ataupun yang lain seperti Musyawarah Nasional.” (Ridho, Pengurus LDII Mendahara, Wawancara)

Berdasarkan hasil wawancara di atas penulis dapat menyimpulkan bahwa organisasi LDII ini selain memiliki intraksi sosial yang baik dengan massyarakat sekitar mereka juga mempunyai rasa kebersamaan dan kebersatuan antar sesama organisasi yang ada di Kelurahan Mendahara Ilir. Cara kelompok LDII mendanai kegiatannya dari dana sumbangan yang tidak mengikat seperti yang dikatakan oleh Ketua LDII di Kelurahan Mendahara Ilir dalam hasil wawancaranya kepada penulis. 
"Sesuai dengan ART Pasal 47, LDII mendapatkan dana dari sumbangan yang diperoleh dari bantuan dan /atau sumbangan sebagaimana dimaksud dalam pasal 44 huruf b Anggaran Dasar tidak mensyaratkan sesuatu apapun kepada dan bagi Lembaga Dakwah Islam Indonesia.” (Agus, Pengurus LDII Mendahara, Wawancara)

\section{EKSISTENSI LDII DI MENDAHARA ILIR}

Keberadaan Lembaga Dakwah Islam Indonesia di Kelurahan Mendahara Ilir merupakan sebuah organisasi kemasyarakatan atau Lembaga Swadaya masyarakat keagamaan yang berhimpun berbagai dari potensi dan bertujuan memberi peningkatan bagi kualitas SDM, kualitas hidup dan berperan serta warga negara dalam kehidupan bermasyarakat, berbangsa dan bernegara sebagai bagian kontribusi untuk mencapai tujuan nasional. Memperhatikan Undang-undang Nomor 8 Tahun 1985 tentang Organisasi Kemasyarakatan; Peraturan Pemerintah Nomor 18 tahun 1986 ; Peraturan dan Menteri dalam Negeri Nomor: 33 Tahun 2012; dan surat dari Ketua Lembaga Dakwah Islam Indonesia (LDII). Nomor: SUM-07/E.5/XI/2014 Tanggal 14 November 2014 Perihal Permohonan Terdaftar. LDII sebagai Organisasi Kemasyarakatan dan dalam melaksanakan kegiatannya agar tidak bertentangan dengan ketentuan perundang-undangan yang berlaku. Seperti yang di katakan oleh Ketua LDII dalam wawancarannya kepada penulis.

"Di Mendahara sendiri, keberadaan organisasi kita ini adalah sebagai Organisasi Kemasyarakatan yang berperan serta untuk meningkatkan pembangunan masyarakata Mendahara baik sosial ekonomi, sosial agama maupun sosial masyarakat. Organisasi kami ini sudah terdaptar di Badan Kesatuan Bangsa dan Politik serta perlindungan masyarakat Mendahara Ilir.” (Baso`, Ketua LDII Mendahara, Wawancara)

Hal yang sama juga dijelaskan oleh Bapak Ramli sebagai masyarakat Mendahara Ilir dalam wawancara kepada penulis.

"Disini, keberadaannya tu, bahwa kelompok warga LDII ini, tidak mengganggu aktivitas masyarakat maupun lingkungan setempat. Dan die ini sebagai organisasi masyarakat yang betul-betul mempunyai nilai 
persatuan yang tinggi dengan sesame warganye maupun masyarakat sini, seperti baik dari segi sosial masyarakat, ekonomi maupun sosial agama. Kan ade cerite nye kelompok die ini gak mau bermasyarakat same-same dielah, saye bace di internet banyak yang aneh2 bapak tengok, kelompok die ni keq inilah keq itulah, semenjak saye tahu hal itu, saye rase tidak adelah yang aneh atau pun yang menyimpang dari keberadaan kelompok die ni dek, baik dari segi sari'at agama maupun pengajiannye. Ini kan sepengetahuan saye dek yang telah bapak tengok emang gak ade yang menyimpang. (Ramli, Masyarakat Mendahara, Wawancara)

Hal yang serupa dijelaskan oleh Ibu Mina sebagai masyarakat Mendahara Ilir dalam wawancaranya kepada penulis.

"Magelo padana rupata, mereka ni kan merupakan organisasi masyarakat yang memiliki rase kebersamaan yang tinggi baik sosial masyarakat maupun sosial ekonomi seperti die ni, pada alena tania sekedar mabbaca nennia napahangito usena angqurange silaingeng pada idi ekkiya mabbacmi anu mabbiase'e rifugau. Tenni'a ga sunnakna nabi'e mappareko matebbe ada-ada lettu makkeda tau ldii yaro narekko riakkai sessok care-carena riaranginange nasengi najisi bate limatta. Narekko matamaki ribolana kolisuni napacingi bateta, naekkiyya ko ifajanengi demua nafakero rilannai narekko engka asiddi sidingeng fada alena amangmua namelo muto maseddi nacueri arisang ko engka gau tudang sipulung melomua sibawa takappo”. (Mina, Masyarakat Mendahara, Wawancara)

Artinya:

'Keberadaan die ni baik dengan masyarakat sini, mereka ini kan merupakan organisasi masyarakat yang memiliki rase kebersamaan yang tinggi baik sosial masyarakat maupun sosial ekonomi seperti die ini, die ni kan mampu menjalankan sunnah rosul. Seperti membace Al-qur'an, mereka bukan sekedar membace tapi isi Al-qur'an tu dikajinye, kalau kite ni kan cuma sekedar membace berbeda dengan nye, kan hal yang wajar dilakukannye tu, kan kalau ngikut sunah nabi, emang keq tu. Banyak gosip 
nye, orang die ni kalau kite angkat jemurnye di anggap najis pakaian yang sudah bekas tangan kite, kalau kite masuk rumah die sudah tu di pel gak ade juge dak ibu tengok. Setelah ibuk tengok- tengok tak adelah die macam tu. Kan ternyate die aman-aman be bermasyarakat dengan kami sekitar mau bergabung, seperti kayak arisan die bergabung dengan kami. Kan itu nunjuk die mau bersosialisasi dengan masyarakat sini'”.

Penulis dapat menyimpulkan, bahwa keberadaan Organisasi LDII ini di Mendahara Ilir yaitu sebagai organisasi masyarakat yang mempunyai nilai sosial agama, ekonomi maupun sosial kemasyarakatan yang tinggi serta memiliki nilai persatuan dan kebersamaan yang baik.Dan secara keberadaanya organisasi LDII ini resmi terdaftar pada tanggal 01 Juni 1972 dengan peraturan pemerintah Nomor 18 Tahun 1986.

Berdasarkan Anggaran Dasar dan Anggaran Rumah Tangga (AD-ART), didirikan organisasi ini di Mendahara Ilir bertujuan adalah untuk meningkatkan kualitas hidup, harkat dan martabak dalam kehidupan bermasyarakat, berbangsa dan bernegara yang islam serta turut serta dalam pembangunan masyarakat Indonesia seutuhnya yang di landasi dengan keimanan dan ketakwaan. Hal ini di ungkapkan Pemimpin dari LDII yang ada di Mendahara Ilir dalam wawancaranya kepada penulis.

"Sesuai dengan Anggaran Dasar dan Anggaran Rumah Tangga Organisasi kita ni dek, kami sebagai pengurus Organisasi bertujuan untuk meningkatkan kualitas kehidupan bermasyarakat, berbangsa dan bernegara yang islam, serta turut dalam pembangunan masyarakat Kelurahan Mendahara Ilir yang sebaiknya, yang dilandasi oleh keimanan dan ketakwaan kepada Tuhan Yang Maha Esa, guna mewujudkan masyarakat yang sejahtera di Kelurahan Mendahara Ilir ini, yang demokratis dan berkeadilan sosial berdasarkan Pancasila yang di ridhoi oleh Allah Subhanahu wa ta'ala. (Baso`, Ketua LDII Mendahara, Wawancara)

Berdasarkan wawancara tersebut penulis dapat menyimpulkan bahwa keberadaan Organisasi LDII bertujuan sebagai Organisasi Kemasyarakatan di 
Kelurahan Mendahara Ilir. Guna mewujudkan masyarakat Kelurahan Mendahara Ilir yang madani, baik dari segi sosial ekonomi, agama maupun sosial masyarakat dan insani yaitu kehidupan sosial masyarakat yang mempunyai nilai keislaman yang tinggi, berdasarkan Al-Qur'an dan Hadits dan dilandasi dengan Keutuhan Yang Maha Esa.

Sesuai dengan tujuan di atas LDII juga mempunyai sasaran untuk mewujudkan di Kelurahan Mendahara menjadi kota yang aman, tentram, bersih berkualitas serta taat kepada Tuhan Yang Maha Esa. Hal ini seperti yang dikatakan Sekretaris Pimpinan Cabang LDII yang ada di Kelurahan Mendahara Ilir.

"Berdasarkan Anggaran dasar dan Anggaran Rumah Tangga (AD-ART) yang kita miliki, Organisasi kita juga mempunyai sasaran yang begitu baik dan berguna untuk masyarakat Kelurahan Mendahara Ilir. Seperti, meningkatkan kegiatan Dakwah islam secara merata di seluruh wilayah di Kelurahan Mendahara Ilir, meningkatkan kualitas hidup masyarakat islam secara merata, meningkatkan pemahaman dan penerapan nilai-nilai islam yang berasal dari sumber-sumber ajaran islam yang murni, meningkatkan partisipasi masyarakat islam dalam berbagai kebijakan dan program dalam pembangunan serta meningkatkan kerukunan beragama dan kesetiakawanan antar sesama umat islam, bangsa maupun negara. Inilah sasaran dari organisasi kami dek, yang perlu diketahui oleh dek". (Ridho, Pengurus LDII Mendahara, Wawancara)

Dari hasil wawancara ini penulis dapat menyimpulkan bahwa organisasi LDII mempunyai sasaran yang begitu baik dan berguna untuk seluruh warganya maupun seluruh warga maupun seluruh masyarakat di Kelurahan Mendahara Ilir yang akan mendatang.

Dalam pengamatan penulis selama melakukan penelitian lapangan, kelompok ini dalam melakukan Sholat Jum'atnya menggunakan Bahasa Arab. Hal ini juga dijelaskan oleh seorang Sekretaris LDII dalam wawncara kepada penulis.

“Emang benar dek, Khutbah Jum'at kelompok kita yang ini menggunakan

Bahasa Arab. Karena tidak ada satupun Ulama yang menyatakan bahwa 
Khutbah Jum'at dengan bahasa Arab itu tidak sah, walaupun berbagai orang tidak seluruhnya bisa memahami isi Khutbah, seperti halnya dek, ketika musim haji di mana Imam Masjid Harom itu menyampaikan Khutbah berbahasa Arab, sedangkan pendengar yang datang dari seluruh belah dunia belum tau bisa mengerti isi Khutbah tersebut. Tapi ada juga yang bisa kok. Tapi gak seluruhnya juga yang bisa”. (Baso`, Ketua LDII Mendahara, Wawancara)

Dalam pengamatan penulis dilapangan. Setiap sudah sembayang sholat Jum'at kelompok mereka ini selalu ada nasehat agama. Hal ini membuat penulis ingin bertanya dalam hal seperti ini. Tapi alhamdulillah direspon pertanyaan penulis dalam wawancaara.

"pada dasarnya orang tu dek memberikan nasehat itu kan bisa dilakukan di setiap ada kesempatan. Karena sudah Sholat Jum'at itu orang-orang kan masih berkumpul, kesempatan itu lah diberikan untuk memberi nasehat dan itu bukan rangkaian dari Sholat Jum'at dek, tapi itu sebagai tambahan pengrtahuan dek." (Baso`, Ketua LDII Mendahara, Wawancara)

Berdasarkan hasil wawancara ini penulis dapat menyimpulkan bahwa setiap Sholat Jum'at kelompok ini menggunakan bahasa Arab dalam Khutbah Jum'atnya serta mendapat nasehat agama setiap sesudah Sholat Jum'at untuk menambah Pengetahuan.

Dalam pengamatan penulis dilapangan organisasi ini, mereka sering berkumpul untuk melakukan kegiatan pengajian baik dari seluruh tingkat pusat maupun dari cabangnya saja. Hal ini sama dengan yang dikatakan oleh Pimpinan Cabang (PC) dalam wawancaranya kepada penulis.

"Disini, kegiatan keagamaan yang di lakukan oleh warga kami LDII antara lain seperti pengajian yang dilaksanakan dari tingkat DPD hingga PAC, dengan mempelajari materi AL-Qur'an dan Al-Hadits". (Baso`, Ketua LDII Mendahara, Wawancara)

Ativitas pengajian kelompok meraka ini merupakan aktivitas yang sangat tinggi karena Al-Qur'an dan Hadits merupakan kajian yang cukup banyak dan 
luas. Hal ini dikatakan seorang ibu susi sebagai kelompok LDII kepada penulis dalam wawancaranya kepada penulis.

" pada idi biasanna makkebbu acara pengajian sibawa gau makkuae tanre, nasaba Al-qur'an sibawa Haddesee alat apparessangengku ya pura matebbe na masagena, ritingkat $P C$ bawang riadakang angajingeng tacciceng siminggu iyanae nasabari onro konrong angajinge marua nalokkai massae”. (Susi, Anggota LDII Mendahara, Wawancara) Artinya:

"Kami selalu menyelenggarakan pengajian dengan aktivitas yang cukup tinggi karena AL-Qur'an dan Hadits merupakan bahan kajian kami yang cukup banyak dan luas, di tingkat PAC saja umumnya pengajian ini diadakan 2-3 kali dalam seminggu sedangkan di tingkat PC diadakan pengajian seminggu sekali. Inilah yang menyebabkan tempat-tempat pengajian kami inii ramai dikunjungi warga."

Dalam pengamatan penulis selama di lapangan kelompok mereka ini mengumpulkan uang untuk Shodaqoh dengan cara melemparkan uang dikarenakan lebih praktis dan bisa menimbulkan suasana dalam berlomba-lomba untuk shodaqoh tapi mereka niat karena Allah. Hal ini sama dikatakan Agus Setiawan kelompok LDII dalam wawancaranya kepada penulis.

"Sebenarnya, banyak cara kami untuk mengumpulkan shodakoh dari warga kami ini seperti di serahkan dan dicatat oleh pengurus, dimasuk ke dalam kotak amal ataupun kami membuat proposal pembangunan Masjid kami, mengenai metode yang pilih sesuai dengan keputusan pengurus setempat.” (Baso`, Ketua LDII Mendahara, Wawancara)

Mendengar isu yang ada seperti pemberitaan di internet maupun pemberitaan lain yang memperburukan nama Organisasi LDII ini dan dikatakan masih sebagai penerus Islam Jamak. Mereka sekarang bukan penerus seperti yang dulu lagi tetapi sebagai Organisasi Kemasyarakatan/ Lembaga Swadaya Masyarakat untuk mensejaterahkan warganya dan membangun masyarakat yang baik, jujur, dapat dipercaya, kerja keras dan hemat, rukun, kompak dan kerja sma 
yang baik. Hal ini dijelaskan oleh ketua LDII sendiri dalam wawancara kepada penulis. (Baso`, Ketua LDII Mendahara, Wawancara)

Dalam wawancaranya kepada penulis Ketua Pimpinan Cabang membantah tuduhan yang ada diberita atau diinformasi dari orang kalau orang yang dikeluar mereka, apabila memasuki masjid mereka kemudian lantainya di cuci.

"Menurut kelompok LDII tidak benar. Jika isu benar, logikanya adalah dari pada kami membersihkan lantai setelah dimasuki seseorang yang bukan warga LDII, tentunya lebih baik melarang siapa yang bukan warganya untuk masuk kemasjidnya tersebut. Sebab alangkah susahnya setiap dimasukki orang yang bukan warganya selalu mencuci lantai. Kenyataan tidak demikian, banyak sekali mesjid LDII terletak di pinggir jalan besar dan bebas untuk dimasukki siapa saja, baik untuk sekedar sholat maupun untuk mengikuti sholat Jum'at." (Baso`, Ketua LDII Mendahara, Wawancara)

Hal ini hampir sama dengan yang dikatakan Pimpinan Cabang dalam wawancaranya kepada penulis tentang berita orang yang diluar kelompok LDII apabila berjabat tangan dengan warga LDII akan di cuci setelah itu.

"Menurut Pimpinan Cabang juga tidak benar, jika isu itu benar, alangkah sulitnya menjadi anggota LDII karena harus mencuci tangan setiap bersalaman dengan orang yang bukan warganya. Kenyataannya banyak warga anak terpelajar LDII dan profesional yang setiap saat bergaul dengan banyak orang dari berbagai kalangan, serta mengikuti etika dalam pergaulan.” (Baso`, Ketua LDII Mendahara, Wawancara)

Dalam wawancara salah seorang kelompok LDII yaitu Ibu Ida yanti juga mengatakan tidak benar warga LDII tidak mau sholat dimesjid lain selain masjid mereka kepada penulis.

"Menurut mereka itu tidak benar, warga LDII selalu berusaha tertib dalam menepati sholat lima waktu, dalam rangka menetapi firman Allah. Untuk menetapi sholat Lima Waktu,warga LDII dapat melaksanakan ibadah sholat di masjid, mushollah, atau temapt ibadah lainnya. Adapun ditempat terdekat ada masjid LDII, tentunya wajar saja jika warga LDII memilih 
pergi ke masjid LDII. Karena dimasjid LDII tersebut dapat diperoleh informasi-informasi mengenai kegiatan organisasi, sekaligus silaturohmi dan menambah ilmu.” (Baso`, Ketua LDII Mendahara, Wawancara)

Dari berbagai tuduhan diatas penulis dapat menyimpulkan wawancara ini bahwa kelompok LDII membantah dengan adanya isu pemberitaan itu karena Lembaga Dakwah Islam Indonesia tidak seperti apa yang dikatakan dengan pemberitaan itu.

Berdasarkan AD / ART Lembaga Dakwah Islam Indonesia Pasal 11 Tentang Upaya dan Prinsip Dakwah ialah menguatakan dan mengembangkan fungsi internal dan eksternal Organisasi, termasuk membangun hubungan dan kerja sama dengan intasi / Lembaga dalam negeri. Kerjasama Hubungan Antar Lembaga bedasrkan AD / ART Pasal 35 yaitu Lembaga Dakwah Islam Indonesia dapat menjalin kerjasama hubungan antar lembaga dengan istansi pemerintah dan/atau nonpemerintah maupun Lembaga independen dan/ atau swasta dalam rangka memperoleh manfaat oleh ketentuan bagi kedua belah pihak, sepanjang diperkenalkan oleh ketentuan peraturan perundang-undangan yang berlaku.

Dari keterangan Baso Palettei ketika masyarakat menolak, dan ingin membubarkan LDII berita itu langsung terdengar oleh pemerintah pusat dan MUI langsung mendatangi kediaman Bapak Baso Palettei di Kelurahan Mendahara dan mengadakan rapat.

Berdasarkan AD/ ART LDII pasal 45 tentang pembubaran organisasi yaitu Lembaga Dakwah Islam Indonesia dapat dibubarkan jika tidak mempunyai kekuatan hidup lagi atau tidak mempunyai anggota dan pemimpinnya, atau tidak adanya kemampuan untuk melanjutkan kegiatan. Ketika keputusan untuk mebubarkan Lembaga Dakwah Islam Indonesia dianggap sah bilamana, mendapatkan persetujuan sekurang-kurangnya3/4 (tiga per empat) dari jumlah suara peserta dalam Musyawarah Nasional Luar Biasa yang diadakan untuk mereka.

Musyawarah dan Rapat Tingkat Cabang terdiri dari Musyawarah Cabang dan Rapat pimpinan Cabang, Musyawarah cabang adalah pemegang kekuasaan tertinggi Organisasi di tingkat Kecamatan yang diselenggarakan sedikitnya sekali 
dalam 5 tahun, dengan kewenangan menetapkan program kerja, memilih dan menetapkan ketua pimpinan cabang dan menilai pertanggungjawaban pempinan cabang. Rapat pimpinan Cabang adalah rapat pengambilan keputusan tertinggi setingkat di bawah Musyawarah cabang dan diselenggarakan oleh pemimpin cabang sesuai kebutuhan.

Menurut informasi yang penulis dapatkan terjadi penolakan pada tahun 80-an ketika LDII ingin membuat masjid sendiri tetapi masyarakat menolak akan adanya pendapat dari LDII tersebut, tetapi dengan terjadinya penolakan tadi LDII mendapatkan dari MUI untuk membangun masjid di lingkungan mereka dan organisasi LDII pun membuat proposal untuk membantu membangunan masjid mereka.

\section{PERKEMBANGAN LDII DI KELURAHAN MENDAHARA ILIR}

Keberadaan organisasi LDII di Kelurahan Mendahara Ilir itu adalah sebagai organisasi yang memperhatikan undang-undang No 8 Tahun 1985 tentang Organisasi Kemasyarakatan, jadi organisasi di sini, yang selalu berupaya menjadikan warganya maupun masyarakat Indonesia untuk berintraksi sosial yang baik dalam membangun masyarakat untuk hidup berdampingan kompak dan kerja sama yang baik.

Berdasarkan Observasi penulis selama melakukan penelitian dilapangan, seperti keberadaanya di Kelurahan Mendahara Ilir, pada awalnya memang terjadi penolakan terhadap organisasi LDII ini, namun dengan berjalannya waktu masyarakat mulai menerima keberadaan organisasi LDII ini dengan baik. Bahkan ia merespon apapun program baik dari pemerintah setempat maupun lingkungan setempat. Adapun upaya pengembangan Organisasi LDII di Mendahara Ilir, sesuai dengan Anggaran Dasar dan Anggaran rumah tangga. Sejalan dengan fungsi Lembaga Dakwah Islam Indonesia sebagai organisasi sosial kemasyarakatan yang berhimpun potensi bangsa dengan tujuan meningkatkan kualitas sumber daya insani, kualitas hidup dan peran serta, sesuai perundanganundangan yang berlaku, serta patuh pada Tuhan Yang Maha Esa. Hal ini di 
jelaskan oleh salah satu dari kelompok organisasi LDII di Mendahara Ilir dalam wawancaranya kepada penulis.

" upaya yang kami lakukan dalam mengembangan Organisasi ini ialah kami membuat proposal untuk mengelurkan dana untuk pembangunan Masjid, dan kami berkerja sama dengan Lembaga baik dalam maupun Luar, untuk meningkatkan sumber insani yang beriman, bertaqwa, berakhlag mulia, menggerakkan sumber daya insani yang memiliki kopetensi informasi, dan untuk menambah ilmu pengetahuan dan teknologi mendorong pembangunan masyarakat yang kompetitif, dengan membangun sikap persaudaraan sesama umat manusia, komunitas muslim serta bangsa dan negara, mematuhi perundang-undangan yang berlaku dan patuh kepada Tuhan Yang Maha Esa. (Ridho, Pengurus LDII Mendahara, Wawancara)

Hal senada juga dikatakan oleh Ketua Pimpinan Anak Cabang dalam wawancaranya dengan penulis.

"Bahwa Organisasi LDII ini merupakan suatu organisasi kemasyarakatan yang berupaya mengembangkan organisasinya. Dengan cara melalui pengajian dan dakwah yang sejuk untuk membangun masyarakat yang lebih baik, jujur, mematuhi perundang-undangan, membangun sikap persaudaraan sesama umat manusia, serta patuh kepada Tuhan Yang Maha Esa.” (Baso`, Ketua LDII Mendahara, Wawancara)

Dari hasil wawancara ini penulis dapat menyimpulkan bahwa kelompok organisasi ini berupaya untuk mengembangkan organisasinya yang bertujuan agar masyarakat di Kelurahan Mendahara Ilir menjadi warga yang baik dan berkualitas.

Dalam suatu lembaga dakwah tentu memiliki objek dakwah mereka sendiri untuk menyampaikan dakwahnya. Sama halnya seperti lembaga dakwah islam di Kelurahan Mendahara Ilir. Objek dakwah dalam pelaksanaan kegiatan dakwah sosial keagamaan mereka yaitu masyarakat umum dan tentunya warga binaan LDII sendiri serta warga pendatang. Dengan adanya suatu objek dakwah, maka pelaksanaan kegiatan dakwah sosial keagamaan LDII dapat berjalan dengan 
baik. Karena, tanpa adanya suatu objek dakwah, pelaksanaan kegiatan dakwah sendiri tidak akan dapat berjalan dengan lancar.

Objek dakwah dalam LDII sendiri bukan hanya orang dewasa saja, tetapi objek dakwah mereka dari anak-anak sampai lansia. Dimulai dari anak-anak karena penting sekali untuk menumbuhkan jiwa dakwah dan pengetahuan dalam diri mereka hingga diharapkan dapat berguna dimasa yang akan datang. Dengan adanya objek dakwah, pelaksanaan kegiatan dakwah sosial keagamaan dapat berjalan sesuai dengan apa yang diharapkan dan dakwah kepada masyarakat dapat di tersampaikan dengan baik sesuai dengan tujuan lembaga dakwah islam Indonesia itu sendiri. Dalam menyampaikan dakwahnya kepada mad'u lembaga dakwah islam indonesia mempunyai berbagai cara dalam menyampaikan seperti dalam rutinitas kegiatan pengajian mereka yaitu:

\section{a. Pengajian bapak-bapak}

Pengajian ini di lakukan khusus untuk bapak-bapak setelah melakukan sholat magrib di hari jum'at, di mana pengajian ini terbuka untuk umum serta materi yang di kaji adalah tafsir qur'an.

\section{b. Pengajian untuk ibu-ibu dan bapak-bapak}

Pengajian ini di laksanakan pada malam rabu, dan malam jum'at untuk mengkaji Al-qur'an dan hadits. Sama halnya dengan kegiatan yang lain, kegiatan ini juga terbuka untuk umum.

\section{c. Pengajian Pra remaja}

Pengajian untuk pra remaja dilaksanakan pada setiap malam senin dan malam minggu ini mengkaji tentang tafsir qur'an dan tafsir hadits. Pengajian ini sendiri terbuka untuk umum bagi siapa saja yang ingin mengikuti pengajian ini tidak hanya di peruntukan untuk warga LDII saja.

\section{d. Pengajian umum (Simpatisan)}

Dalam pengajian umum ini ada beberapa jadwal pelaksanaannya yaitu:

1) Pengajian ini di lakukan pada setiap kamis dan malam sabtu. Pengajian ini terbuka untuk umum dan tidak terbatas usia bagi yang ingin mengikutinya. 
Pada pengajian umum yang di laksanakan setiap malam kamis dan malam sabtu ini, materi yang akan di kaji yaitu tafsir qur'an dan tafsir hadist.

2) Pengajian umum ini dilaksanakan setiap minggu dan jum'at. Pada hari jum'at materi yang akan di kaji yaitu tafsir qur'an dan pada hari minggu materinya tafsir hadits.

3) Pengajian umum ini dilaksanakan setiap sabtu pada minggu kedua dan minggu keempat. Pengajian umum ini akan dilaksanakan pada pukul 13:00 siang sampai waktu ashar. Materi yang akan dikaji pada pengajian ini yaitu tafsir hadits. Sama halnya dengan pengajian yang lain. Pengajian ini terbuka untuk umum bagi siapa saja yang ingin datang. (Baso`, Ketua LDII Mendahara, Wawancara)

4) Adanya pengajian dakwah da'i dan da'iyah yang sering di sebut dengan istilah mubaligh dan mubalighah yang di laksanakan oleh seluruh warga lembaga dakwah islam indonesia tingkat PC.

5) Pengajian untuk Anak-Anak

Kelompok kegiatan ini disebut dengan istilah "cabe rawit" mulai dari usia 7-10 tahun. Kegiatan pengajian ini hampir di laksanakan setiap hari di mulai dari hari senin sampai dengan hari sabtu. Kegiatan pengajian cabe rawit di bagi menjadi 2 tahap yaitu:

1. Tahap I bagi siswa yang bersekolah siang, pengajian dilaksanakan pada pagi hari di mulai 08:00-09:00.

2. Tahap II bagi siswa yang bersekolah pagi, pengajian dilaksanakan pada sore hari di mulai pada pukul 16:00-17:00 senin sampai dengan hari sabtu.

Adapun materi yang disampaikan dalam pengajian anak-anak ini seperti tajwid, tilawatih, qiroad serta kegiatan ekstra lainnya seperti adzan, kaligrafi, dan Asmaul Husna. Dengan diadakannya rutinitas kegiatan yang telah terjadwalkan dengan baik, maka di harapakan dalam pelaksanaan kegiatan dakwah sosial keagamaan dapat berjalan dengan lancar. Dan materi yang disampaikan oleh da'i dan mad'u dapat di mengerti dan di pahami dengan baik. 


\section{a. Media Dakwah}

Media dakwah adalah factor yang dapat menentukan kelancaran proses pelaksanaa dakwah. Melihat jaman sekarang yang sudah cukup canggih dan maju, pasti setiap lembaga dakwah dalam menyampaikan dakwhanya sangatlah aktiv dan terpacu untuk menyampaikan tentang tujuan dan dakwah mereka. Adapun alat-alat yang dipakai untuk menyampaikan ajaran islam.

1. Lisan, inilah media dakwah yang paling sederhana yang menggunakan lidah dan suara. Media ini juga dapat berbentuk pidato, ceramah, kuliah, bimbingan, penyuluhan, dan sebagainya.

2. Tulisan, seperti buku, majalah, Al-Qur'an dan

3. khlak, yaitu perbuatan-perbuatan nyata yang mencerminkan ajaran islam, yang dapat dinikmati dan di dengar oleh mad'u.

\section{b. Lingkungan}

Keberhasilan suatu kegiatan dakwah tentu tidak lepas dari dukungan lingkungan sekitar. Sama halnya dengan kegiatan dakwah yang diadakan oleh LDII di Kelurahan Mendahara Ilir sendiri, selama ini dalam pelaksanaan kegiatan dakwah mereka, lingkungan sangat kondusif. Semenjak keberadaan LDII Pimpinan anak cabang di Kelurahan Mendahara Ilir, berjalan dengan harmonis dengan lingkungan dan bersosialisasi dengan diadakannya agenda kegiatan sebulan sekali yang disebut dengan MINCE (minggu ceria) yaitu bekerja bakti bersama-sama seluruh warga yang bergabung dengan warga lingkungan rt untuk bersama-sama membersihkan lingkungan kompleks masjid serta di luar kompleks masjid.

Susunan Pengurusan Lembaga Dakwah Islam Indonesia:

\begin{tabular}{|l|l|l|l|}
\hline NO & Nama & Jabatan & Alamat \\
\hline 1. & Baso Palettei & Ketua & Mendahara ilir \\
\hline 2. & Umri Ridho & Seketaris & Mendahara ilir \\
\hline 3. & Agus Setiawan & Bendahara & Mendahara ilir \\
\hline 4. & -Heru & Imam & Mendahara ilir \\
\hline
\end{tabular}




\begin{tabular}{|l|l|l|l|}
\hline & -Baso Palettei & & \\
\hline 5. & Bedu Amin & Bilal & Mendahara ilir \\
\hline 6. & $\begin{array}{l}\text { Ustad Faisal } \\
- \text { Ros }\end{array}$ & Guru Ngaji & Mendahara ilir \\
\hline 7. & Amri & Khatib & Mendahara ilir \\
\hline
\end{tabular}

Berdasarkan AD/ART LDII Pasal 1, keanggotaan LDII terdiri dari anggota tetap dan tidak tetap yang biasanya disebut Simpatisang berdasarkan hasil wawancara dengan Bapak Baso' menjelaskan bahwa anggota tetap berjumlah 200 dan anggota tidak tetap 50 yang mana anggota tetap adalah pengurus dan atau pengurus yang sudah pernah tugas dari kepengurusan organisasi yang memenuhi ketentuan. Selanjutnya yang disebut anggota tidak tetap adalah anggota yang tidak termasuk dalam ketentuan organisasi dan yang bersedia mengikuti kegiatan dakwah keagamaan dan pendidikan kemasyarakatan yang diselenggarakan oleh organisasi.

Dalam suatu organisasi terdapat Anggota ataupun pengurus, pengurus adalah Anggota Tetap yang terpilih dalam Musyawarah tertinggi pada tiap tingkat kepengurusan organisasi untuk mencapai maksud dan tujuan organisasi. Berdasarkan Keputusan Musyawarah Nasional VII Lembaga Dakwah Islam Indonesia.

Lembaga Dakwah Islam Indonesia didirikan dengan maksud untuk menghimpun seluruh potensi bangsa yang memilih persamaan cita-cita, wawasan, dan tujuan, sehingga memiliki satu visi dan persepsi dalam menggalang persatuan dan kesatuan bangsa dalam Negara Kesatuan Republik Indonesia yang berdasarkan Pancasila dan Undang-Undang Dasar 1945. Lembaga Dakwah Islam Indonesia bertujuan untuk meningkatkan kulitas peradaban, hidup, harkat dan martabat dalam kehidupan bermasyaraka, berbangsa dan bernegara, serta turut serta kedalam pembangunan manusia Indonesia seutuhnya berlandaskan keimanan dan ketakwaan kepada Tuhan Yang Maha Esa dalam rangka mewujudkan masyarakat madani yang demokratis dan berkeadilan sosial 
berdasarkan Pancasila yang diridhoi Allah Subhanahu Wa Ta'ala. (MUSNAS VII LDII, Pasal 6)

Berdasarkan Keputusan Musyawarah Nasional VII Lembaga Dakwah Islam Indonesia dalam pasal 17 untuk tugas dan wewenang serta kewajiban pengurus. Untuk dewan pimpinan pusat berwewenang dalam menentukan kebijakan organisasi di tingkat Nasional sesuai ketentuan Anggaran Dasar, dan Anggaran Rumah Tangga serta keputusan Musyawarah Nasional/ Musyawarah Nasional Luar Biasa, serta kewajibannya melaksanakan seluruh kebijakan organisasi sesuai ketentuan Anggaran Dasar, dan Anggaran Rumah Tangga dan memberikan pertanggung jawaban kepada Musyawarag Nasional.

Dari beberapa tingkat kepengurusan dan wewenang organisasi LDII di Kelurahan Mendahara termasuk dalam tingkat PC ( Pimpinan Cabang) yaitu tugas dan wewenang serta kepengurusan ialah menentukan kebijakan organisasi di tingkat Kecamatan sesuai ketentuan Anggaran Dasar, Anggaran Rumah Tangga, keputusan-keputusan Musyawarah dan Rapat baik tingkat Pusat, Wilayah, Daerah maunpun Kecamatan, dan Peraturan organisasi, mengusulkan hasil ketetapan Musyawarah Cabang/ Musyawarah Cabang Luar Biasa tentang komposisi dan personalia Pimpinan Cabang untuk mendapatkan persetujuan Dewan Pimpinan Daerah, mengesahkan komposisi dan personalia Pimpinan Anak Cabang dan menyelesaikan perselisihan kepengurusan Pimpinan Anak Cabang. Untuk Pimpinan Cabang berkewajiban untuk melaksanakan seluruh kebijakan organisasi di tingkat Kecamatan sesuai ketentuan Anggaran Dasar dan Anggaran Rumah Tangga, melaksanakan tugas-tugas lain yang ditetapkan Dewan Pimpinan Daerah dan memberikan pertanggungjawaban kepada Musyawarah Cabang/ Musyawarah Cabang Luar Biasa. (MUSNAS VII LDII, Pasal 17)

\section{PENUTUP}

Kesimpulan dari hasil penelitian "Sejarah dan Eksistensi LDII di Kelurahan Mendahara Ilir, Kecamatan Mendahara Kabupaten Tanjung Jabung Timur" adalah sebagai berikut: 
1. Yang membawa LDII di Kelurahan Mendahara Ilir yaitu H. Mursidin yaitu pada tanggal 01 Juli 1972, Lembaga Dakwah Islam Indonesia adalah Organisasi keagamaan. Awalnya, organisasi ini di tolak oleh masyarakat karena menurut mereka organisasi LDII memiliki paham yang berbeda dengan masyarakat Mendahara. Akan tetapi dengan adanya penolakan terhadap organisasi ini mereka tetap eksis dan berkembang hingga sekarang. Bahkan organisasi ini telah terdaftar sebagai Organisasi Kemasyarakatan dan surat keterangan terdaftar ini berlaku sejak tanggal di tandatangani sampai dengan 13 November 2019.

2. Berdasarkan observasi penulis selama melakukan penelitian dilapangan, seperti layaknya keberadaan LDII di Kelurahan Mendahara Ilir, interaksi kelompok LDII dengan masyarakat sekitar berjalan dengan sangat baik dan tidak mengganggu masyarakat sekitar maupun sosial ekonomi masyarakat sekitar. Bahkan ia selalu merespon apapun program baik dari pemerintah setempat maupun lingkungan setempat pula.

3. Adapun upaya yang di lakukan kelompok LDII dalam pengembangan Organisasinya LDII di Kelurahan Mendahara Ilir, sesuai dengan Anggaran Dasar dan Anggaran Dalam Rumah Tangga. Sejalan dengan fungsi Lembaga Dakwah Islam Indonesia sosial kemasyarakatan yang menghimpun potensi bangsa dengan tujuan meningkatkan kualitas hidup dan peran serta, sesuai dengan perundang-undangan yang berlaku. Membangun hubungan kerjasama dengan Lembaga baik dalam maupun luar, mungkin sumber daya insani yang memiliki kompetensi informasi, ilmu pengetahuan dan teknologi, mendorong pembangunan masayarakat madani yang kompetitif, dengan membangun sikap persaudaraan sesama umat manusia, komunitas muslim, serta bangsa dan negara, mematuhi perundang-undangan yang berlaku dan patuh kepada Tuhan Yang Maha Esa.

\section{DAFTAR PUSTAKA}

\section{BUKU}

Agus, Bustanuddin, 2006 Agama Dalam Kehidupan Masyarakat( Jakarta : PT Raja Grafindo Persada 
Abdurrahman, Dudung, 2011 Metode Penelitian Sejarah Islam. Yogyakarta: Penerbit Ombak,

Abdurrahman Dudung, 2007 Metode Penelitian Sejarah. Yogyakarta: Ar-auuz medi.

Basrowidan Suwandi. 2008. Memahami Penelitian Kualitatif. Jakarta: Rineka Cipta.

Endraswara, Suwandi. 2006 . Metode, Teori, Teknik Penelitian Kebudayaan: Ide ology,Epistemologi,dan Aplikasi. Jakarta: Pustaka Widyatama.

H.Frederick William. Pemahaman Sejarah Indonesia, Lembaga penelitian pendidikan ekonomi dan sosial.

Koentjaraningrat, 1982 Sejarah Teori Antropologi, Penerbit: Universitas Indonesia UI-Press

Moleong, Lexy J. 2005, Metodologi Penelitian Kualitatif. Bandung: PT Remaja Rosdakarya.

Priyadi, Sugeng 2017, Sejarah Lisan. Yogjakarta: Penerbit Ombak

Sutiyono. 2010. Benturan Budaya Islam:Puritan dan Sinkretis. Jakarta: Kompas

Sugiyono, 2009 .Metode Penelitian Kuantitatif, Kualitatif Dan $R \&$ D, Bandung: Alfabeta

\section{JURNAL}

Harianti 2000 . Penulisan Sejarah Sosial No 1

Mahendra Bimo 2017. Eksistensi Sosial Remaja Dalam Instgram, vol 16, No 1

Otoman, 2014. Asal usul dan perkembangan lembaga dakwah indonesia, vol 14, No 2

Saefrudin 2017. Jurnal Al-Hikmah, Vol. 5 No 2

Sya'roni,2005. Jurnal penelitian sosial keagamaan, vol 20, no 2. 